\title{
How Useful Is It for Banks to Analyze Financial Statements
}

\author{
Wanchao Liu \\ Newcastle Business School, Newcastle University, Newcastle upon Tyne, UK \\ Email:875640849@qq.com
}

How to cite this paper: Liu, W. C. (2020) How Useful Is It for Banks to Analyze Financial Statements. American Journal of Industrial and Business Management, 10, 1488-1504.

https://doi.org/10.4236/ajibm.2020.108098

Received: August 6, 2020

Accepted: August 28, 2020

Published: August 31, 2020

Copyright $\odot 2020$ by author(s) and Scientific Research Publishing Inc. This work is licensed under the Creative Commons Attribution International License (CC BY 4.0).

http://creativecommons.org/licenses/by/4.0/

(c) (i) Open Access

\begin{abstract}
Within the last decades, under the continuous advancement of human commercial civilization, the tide of economic globalization has swept through every corner of the world. Accounting, as a precise "business language", is in the context of cultural, linguistic and social systems. The disclosure and communication of business information plays a crucial role and is increasingly valued by people from all walks of life. The financial statements, as a major carrier to reflect the financial position, business activities and cash flow of the enterprise, are also affecting the interests of all parties and bearing the extraordinary significance (Berger et al., 2015: p. 2286). Because of this, how to analyze and interpret financial statements has become a topic that needs to be continuously researched and explored in the new century. According to Shopify (2019), financial statements are defined as the accounting form of reflecting on an overall picture of the health of a business, including cash flow statement, the income statement and the balance sheet of the business. It can provide financial position performance and changes for a corporation. Investors or financial workers can uncover financial risk factors from qualitative textual risk disclosures reported in financial statements, especially bank risks.
\end{abstract}

\section{Keywords}

Financial Statements, Bank Risk, Financial Ratios, Solvency, Profitability

\section{Introduction}

Bank risk is defined as a type of business risk which results in the possibility of suffering losses of economy, assets or income due to the influence of uncertainty factors during the process of commercial bank operation, including credit risk, market risk, liquidity risk, legal risk, management risk, interest rate risk and exchange rate risk (Wei et al., 2019: p. 10). In addition, the financial position of 
bank can reflect the situation of global financial market, which could perform in financial crisis or avoid financial crisis. For example, when a financial crisis is coming, depositors who placed more importance on deposit security could increase a large number of deposits into a bank. However, due financial crisis, the production invested in other industry suffers severe loss or is in the red, resulting in substantial bad debts so that the bank is insolvent, such as Washington Mutual and Lehman Brothers bank (Langer et al., 2014: p. 524). Also, the financial position of bank and trend of depositor can be reflected in financial statements. Hence, analyzing financial statement to obtain a situation of asset and liabilities is becoming increasingly crucial for a banker.

According to Penman (2012), financial statement analysis and evaluation was first created by American banker Alexander Wall. High significant amount of data volume in financial statements so that financial statements of a commercial bank are usually up to hundreds of papers. For example, the cash flow statement from financial statements can reflect on the bills and purchase stock in order to determine if the business is able to repay loans (Green, 2013: p. 6). Also, it also can provide information about the profit and problems for a business. The income statement, which represents the income, expenses, net profit and earnings per share for one year or quarter, is based on the accounting formula "profit = revenue - cost." (Sasmaz, 2015). Through the analysis of the income statement, we can assess the completion of the company's profits, understand the profitability of the company and the changes in profit and loss, so as to predict the future business profits of the company. El Fayoumi (2018) shows that the balance sheet is an accounting statement that reflects the financial status of a company on a specific date. The assets owned by the company and the company's arrears to external creditors and the arrears of internal creditors constitute a balance, based on the equation "assets = liabilities + owner's equity." The left side of the balance sheet reflects the financial status of the enterprise, and the assets are listed in terms of their liquidity from large to small; the right side demonstrates the debt and shareholder equity of the enterprise, indicating the proportion of the source of funds between the creditor and the business owner (Barnes \& Warman, 2000). It provides financial information such as the company's asset structure, asset liquidity, source of funds, debt level, and liability structure. Thus, according to financial tools to analyze each part of financial statements is useful for avoiding financial risks.

Hence, this essay aims to analyze how effectively to use financial statement and how useful it is for a bank. For showing results clearly, this essay takes Bank of America as a case to analyze the relationship between risks and financial statements. This bank resisted the 2008 financial crisis and buy Merrill Lynch and Countrywide Financial Corp. After that, Bank of America takes control of the largest stockbroker team and one of the largest commercial banks in the US. Therefore, this bank holds a high risk avoidance, which is a good example as a case of this essay to analyze. In addition, financial statements can reflect much 
other information, such as solvency, profitability, return on net assets and operation ability. China Bank of Communications, as one of the oldest banks in China, profits continuously for more than ten years. However, profitability is declining. Asset utilization keeps increasing. Hence, this is a good case to analyze multi-faceted ability according to analyze financial statements. In Section 2, it will demonstrate three main parts of financial statements and evaluate the function and reliability of them reflecting on asset and liability structure positively, which could have different effects for a bank to understand financial situation. Section 3 describes various methods used in the practice of financial statements analysis and the advantages and disadvantages of different methods. In Section 4 , it will analyze the importance of financial statements for a bank and how to avoid risk depending on the information what be uncovered from financial statements.

\section{Composition of Financial Statements}

\subsection{Cash Flow Statement}

\subsubsection{The Definition of Cash Flow Statement}

According to Green (2013: p. 2), the cash flow statement can reflect the inflow and outflow of cash and cash equivalents of an organization during a certain accounting period. It can help users to understand and evaluate the profitability of a bank even predict the future cash flow of the company (Green, 2013: p. 4).

\subsubsection{Structure of Cash Flow Statement}

As Figure 1 about the cash flow of bank of America shows, it explains the asset and liability items in 2017, which can help the bank to analyze the information about the balance of operating, investment and financial activities. For example, net cash provided by operating activities is 10.40 billion dollars, which indicates cash inflow is more than cash outflow in 2017 and bring enough net cash flow for this bank to operate. In contrast, negative net cash flow can speculate that this bank has some problems in operating or managing. Because what commercial bank operate is currency, this operating activities mainly refer to Proceeds from sales and paydowns of loans originally classified as held-for-sale and deposits (Wagner, 2019). In addition, net cash flow used in investing activities is -52 billion dollars, which means bank of America is expanding capital and assets. Another important part in cash flow statement is net cash provided by financing activities which gets up to 49.19 billion dollars in this table. According to Li et al., (2017: p. 686), this means that this bank has external debt or equity capital inflow. This type of inflow may be because that the magnifying effect of the bank's financial leverage through borrowing, which is what financial managers want (Li et al., 2017: p. 687).

\subsection{Income Statement}

\subsubsection{The Definition of Income Statement}

Another crucial part in financial statements is income statement. Generally, 
Adjustments to reconcile net income to net cash provided by operating activities:

Provision for credit losses

Gains on sales of debt securities

Depreciation and premises improvements amortization

1482

Amortization of intangibles

Net amortization of premium/discount on debt securities $\quad 2251$

Deferred income taxes

8175

Stock-based compensation

Loans held-for-sale:

Originations and purchases

Proceeds from sales and paydowns of loans originally classified as held-for-sale

Net change in:

Trading and derivative instruments

Other assets

$(19,859)$

Accrued expenses and other liabilities

4673

Other operating activities, net

7424

Net cash provided by operating activities

10,403

Investing activities

Net change in:

Time deposits placed and other short-term investments

Federal funds sold and securities borrowed or purchased under agreements to resell

Debt securities carried at fair value:

Proceeds from sales

73,353

Proceeds from paydowns and maturities

93,874

Purchases

$(166,975)$

Held-to-maturity debt securities

Proceeds from paydowns and maturities

16,653

Purchases

Loans and leases:

Proceeds from sales $\quad 11,761$

Purchases

Other changes in loans and leases, net

Other investing activities, net

\section{Financing activities}

Net change in:

Deposits

Federal funds purchased and securities loaned or sold under agreements to repurchase

Short-term borrowings

Long-term debt:

Proceeds from issuance

Retirement of long-term debt

Preferred stock: Proceeds from issuance

Common stock repurchased

Cash dividends paid

Other financing activities, net

Effect of exchange rate changes on cash and cash equivalents $\quad 2105$

Net increase (decrease) in cash and cash equivalents $\quad 9696$

Cash and cash equivalents at January 1

Cash and cash equivalents at December $31 \quad \$ \quad 157,434$

Supplemental cash flow disclosures

Interest paid

\$ 12,852

Income taxes paid

Income taxes refunded

Figure 1. Cash flow statement. (Source from: Financial report of Bank of American in 2017). 
income statement provides company with the situation of earning which can help company understand the profitability and the return to equity holders, including gross profit, operation profit and profit before taxation (Subramanyam, 2009: p. 22). Different profit can reflect different financial function. Specifically, gross profit, also called gross margin, is that sales minus cost of sales, which can show the profit situation of the main business items. Operation profit refers to a type of profit which is the retention of the company after paying the income tax in the total profit (Brown, 2012: p. 1002). It usually is used as the difference between sales and all operating costs and expenses. In addition, profit before taxation, as the name implies, is the taxable profit before the enterprise pays the income tax, which is usually from continuing operations before paying tax for government (Sasmaz, 2015: p. 190).

\subsubsection{Structure of Income Statement}

However, for bank, interest earned, net interest income, non-interest income and net income are the most common description (Wagner, 2019). For example, Figure 2 shows total interest income of bank of America in 2017, the green line, got up to 57.5 billion dollars which is from loans, investments and cash positions. In addition, net interest income was 44.6 billion dollars, which mainly includes the spread between interest earned from loans and the interest paid out to depositors. For protecting bank from any negative moves in yield, earning income from non-interest rate related products is an excellent way for bank to gain more profit. As the table shows, bank of America totaled 42.6 billion dollars for non-interest income in 2017. According to Wagner (2019), this includes bank account and service fees, trust income, loan and mortgage fees, brokerage fees and wealth management services income, and income from trading operations. Net income, also called net profit, is 18.2 billion dollars for 2017 .

Because of different operation, revenue for bank has great difference with company, like private limited company (Breuer et al., 2010: p. 706). According to Breuer et al., (2010: p. 707), the total of the net-interest income and non-interest income is crucial profit, usually using it to calculate revenue for bank. Due to total interest income includes expenses, revenue number can be inflated when calculating. In addition, some bank activities may be affected due to changes in interest rates. The rising of interest rate, for instance, can typically cause the declines of the volume of residential mortgage loan originations. Moreover, slower payments can occur on mortgage-servicing pools when interest rate rises, which is because borrowers have less likely to refinance (Breuer et al., 2010: p. 706). Hence, this table shows bank of America has a balanced revenue which comes mostly from fee income and mortgage servicing-related businesses. According to this analysis, these types of income can help bank to increase and keep stable finance to decline risk when moderately rising interest rates. Besides, another benefit for bank is that more interest income on variable-rate loans can be earned by bank when interest rate rises (Grundke, 2009: p. 216). It is because that bank can increase the rate what they charge borrowers like credit cards. Unfortunately, 
Consolidated Statement of Income

(Dollars in millions, except per share information)

2017

Interest income

Loans and leases

$\$ \quad 36,221$

Debt securities

10,471

Federal funds sold and securities borrowed or purchased under agreements to resell $\quad \mathbf{2 3 9 0}$

$\begin{array}{lr}\text { Trading account assets } & \mathbf{4 4 7 4}\end{array}$

Other interest income $\quad 4023$

$\begin{array}{lr}\text { Total interest income } & \mathbf{5 7 , 5 7 9}\end{array}$

Interest expense

Deposits 1931

Short-term borrowings $\quad 3538$

Trading account liabilities $\quad 1204$

Long-term debt $\quad \mathbf{6 2 3 9}$

\begin{tabular}{lr} 
Total interest expense & 12,912 \\
\hline
\end{tabular}

$\begin{array}{ll}\text { Net interest income } & \mathbf{4 4 , 6 6 7}\end{array}$

Noninterest income

Card income $\quad 5902$

$\begin{array}{lr}\text { Service charges } & \mathbf{7 8 1 8}\end{array}$

Investment and brokerage services $\quad 13,281$

$\begin{array}{lr}\text { Investment banking income } & \mathbf{6 0 1 1}\end{array}$

$\begin{array}{ll}\text { Trading account profits } & \mathbf{7 2 7 7}\end{array}$

Mortgage banking income $\quad 224$

Gains on sales of debt securities

Other income $\quad 1917$

$\begin{array}{lr}\text { Total nominterest income } & \mathbf{4 2 , 6 8 5}\end{array}$

$\begin{array}{lr}\text { Total revenue, net of interest expense } & \mathbf{8 7 , 3 5 2}\end{array}$

$\begin{array}{lr}\text { Provision for credit losses } & 3396\end{array}$

Noninterest expense

$\begin{array}{lr}\text { Personnel } & \mathbf{3 1 , 6 4 2}\end{array}$

$\begin{array}{lr}\text { Occupancy } & 4009\end{array}$

Equipment $\quad 1692$

$\begin{array}{ll}\text { Marketing } & 1746\end{array}$

Professional fees $\quad 1888$

Data processing $\quad 3139$

Telecommunications $\quad 699$

Other general operating $\quad 9928$

Total nominterest expense $\quad \mathbf{5 4 , 7 4 3}$

Income before income taxes $\quad 29,213$

$\begin{array}{lr}\text { Income tax expense } & 10,981\end{array}$

$\begin{array}{ll}\text { Net income } & \$ 18,232\end{array}$

\begin{tabular}{lr}
\hline Preferred stock dividends & $\$ 18,232$ \\
\hline
\end{tabular}

$\begin{array}{ll}\text { Net income applicable to common shareholders } & \$ 16,618\end{array}$

$\begin{array}{ll}\text { Net income } & 18,232\end{array}$

Other comprehensive income (loss), net-of-tax:

Net change in debt and marketable equity securities $\quad 61$

Net change in debit valuation adjustments

$\begin{array}{lr}\text { Net change in dervatives } & \mathbf{6 4}\end{array}$

Employee benefit plan adjustments $\quad 288$

Net change in foreign currency translation adjuscments $\quad \mathbf{8 6}$

\begin{tabular}{lr} 
Other comprehensive income (loss) & 206 \\
\hline
\end{tabular}

\begin{tabular}{llr} 
Comprehensive income & $\$ 18,438$ \\
\hline
\end{tabular}

Figure 2. Income statement. (Source from: Financial report of Bank of American in 2017). 
over high interest rate can decline the demand of credit and lead to the decreasing of economic profit so that bank get less net income (Wagner, 2019).

\subsection{Balance Sheet}

\subsubsection{The Definition of Balance Sheet}

A balance sheet is a statement that reflects a company's financial position on a particular date. Subramanyam (2014: p. 20) states that by providing a balance sheet, it can reflect the liability and assets and help the financial statement users to understand the financial position of a bank.

\subsubsection{Structure of Balance Sheet}

Assets listed in the balance sheet is a type of capital controlled by a bank during a period of trade and that are expected to bring economic benefits to the business, including current asset and non-current asset (Li et al., 2017: p. 673). In addition, liability listed in the balance sheet is another important part, which reflects the current obligations of a bank during a tradecycle. Liabilities should be presented in the balance sheet in terms of current liabilities and non-current liabilities (El Fayoumi, 2018: p. 113).

According to analyze balance sheet of a bank, it is very clear for manager and bank investor to understand the financial position and capital of bank, which can help bank investor to make investing decision (El Fayoumi, 2018: p. 120). For example, as the Figure 3 about the balance sheet of bank of America, cash and cash equivalents which stands for deposit can help managers and analysist to decide that whether increase dividend or not. Also, the largest responsibility for the bank is to ensure the safety of deposit and help depositor to manage property, including money-market accounts, savings, and checking accounts, which can affect the ability of bank to lend (Berger et al., 2015: p. 2289). This can lead to lower loan growth even have more liabilities from interbank to meet loan demand when lack of deposit.

\subsection{Statement of Change in Equity}

\subsubsection{The Definition of Statement of Change in Equity}

Statement of change in equity refers to a statement reflecting changes in the current period of each component that constitutes the shareholder's equity. Valand (2011: p. 9) describes that it can explain that shareholder's equity could change follow the profit and loss of the business operation within a period of time, which is the most important information about whether management is fair to shareholders.

\subsubsection{Structure of Statement of Change in Equity}

For indicating the current period of changes in the components that constitute the owner's equity clearly, it is usually lists in the form of a matrix ( $\mathrm{Li}$ et al., 2017: p. 683). On one hand, it lists a transaction or event that causes a change in owner's equity, which is a comprehensive reflection of changes in shareholder's equity over a period of time from the source of changes in shareholder's equity. 
Held-to-maturity, at cost (fair value - $\$ \mathbf{1 2 3 , 2 9 9}$ and $\$ 115,285 ; \mathbf{6 0 0 7}$ and $\$ 8233$ pledged as collateral)

Premises and equipment, net 9,247

Mortgage servicing rights 2,302

Goodwill

Loans held-for-sale (includes $\$ 2,156$ and $\$ 4,026$ measured at fair value)

Customer and other receivables

Assets of business held for sale (includes $\$ 619$ measured at fair value at December 31,2016 )

Other assets (includes $\$ \mathbf{2 0 , 2 7 9}$ and $\$ 13,802$ measured at fair value)

Assets of consolidated variable interest entities included in total assets above (isolated to settle the liabilities of the variable interest entities)

Trading account assets

Loans and leases

48,929

Allowance for loan and lease losses

Loans held-for-sale 27

All other assets 1,694

Total assets of consolidated variable interest entities $\$ 56,155$

(Dollars in millions)

\section{Assets}

Deposits in U.S. offices:

Noninterest-bearing

Interest-bearing (includes $\mathbf{\$ 4 4 9}$ and $\$ \mathbf{7 3 1}$ measured at fair value)

$\$ \quad 430,650$

Deposits in non-U.S. offices:

Noninterest-bearing

796,576

Interest-bearing

14,024

Total deposits $\quad \mathbf{1 , 3 0 9 , 5 4 5}$

Federal funds purchased and securities loaned or sold under agreements to repurchase (includes $\$ 36,182$ amd $\$ 35.766$ measured at fair value)

Trading account liablities

81,187

Derivative liabilities

Short-term borrowings (includes $\$ 1,494$ and $\$ 2,024$ measured at fair value)

34,300

Accrued expenses and other liabilities (includes $\mathbf{\$ 2 2 , 8 4 0}$ and $\$ 14,630$ measured at fair value and $\mathbf{\$ 7 7 7}$ and $\$ 762$ of reserve for unfunded lending

32,666

commitments)

152,123

Long-term debt (includes $\$ \mathbf{3 1 , 7 8 6}$ and $\$ 30,037$ measured at fair value)

Commitments and contingencies (Note 6 - Securitizations and Other Variable Interest Entities, Note 7 - Representations and Warranties Obligations

and Corporate Guarantees and Note 10 - Commitments and Contingencies)

Shareholders' equity

Preferred stock, $\$ 0.01$ per value; authorized - 100,000,000 shares; issued and outstanding - 3,837,683 and 3,887,329 shares

Common stock and additional paid-in capital, $\$ 0.01$ par value; authorized $-\mathbf{1 2 , 8 0 0 , 0 0 0 , 0 0 0}$ shares; isued and outstanding - 10,287,302,431 and

$10,052,625,604$ shares

Accumulated other comprehensive income (loss)

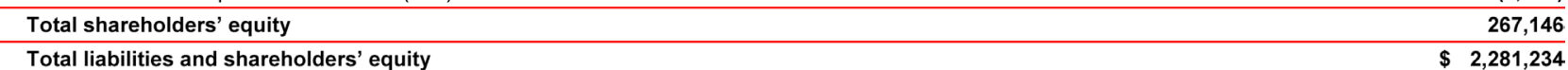

Liabilities of consolidated variable interest entities included in total liabilities above

Short-term borrowings

Long-term debt (includes $\$ 9872$ and $\$ 10,417$ of non-recourse debt)

All other liabilities (includes $\$ 34$ and $\$ 38$ of non-recourse liabilities)

Figure 3. Balance sheet. (Source from: Financial report of Bank of American in 2017). 
On the other hand, it lists the effects of a transaction or event on the shareholder's equity based on the components of the shareholder's equity and their total amount.

\section{Methods of Financial Statement Analysis}

There are lots of analysis methods for financial statements. On one hand, for analysing corporation value by using financial statements, for instance, financial worker can expound the relationship between financial statements and corporate value to predicting the future value of enterprises (Penman, 2012). On the other hand, investor can use financial statement framework or build structures by using financial statements data to achieve strategy investment (Valand, 2011). Besides these, from the perspective of financial statement analysis methods, the methods used in the practice of financial analysis are mainly comparative analysis, time series analysis, ratio analysis, and empirical analysis. However, the current theoretical system has also continually revised and developed these methods. For example, the traditional ratio analysis formula is too simple, which restricts the practicability of the analysis, thus introducing a more complex mathematical analysis method (Penman, 2012). In order to solve liquidity problems of management for a corporation and make decisions, fuzzy set theory is also introduced in the ratio analysis method.

\section{Analysis of Bank Risks Based on Financial Statements}

High-leveraged business is the most significant feature of bank, including deposit and loan. This means bank industry has to face different type of financial risks which are mainly interest rate risk, credit risk and operating risk. According to Li et al., (2017: p. 686), regulators take the responsibility for bank to check minimal capital to help ensure the capability for risk-bearing and solvency of bank. For example, in the US, the Federal Reserve System (FRS), the Federal Deposit Insurance Corporation (FDIC), the Office of Thrift Supervision, and the Office of the Comptroller of the Currency focus on checking and dictate annual financial statement of each bank to insure operating and leverage-bearing compliance which can keep bank be sound and integrity (Krause et al., 2017: p. 118).

\subsection{Bank Risks Factors Related to Financial Statements}

A significant benefit of financial statements is that it can reflect many financial risks and provide a warning for bank to avoid risks, such as credit risk and interest rate risk. Credit capital business is the most crucial and traditional business for bank, which holds very high percentage of total asset in financial statement and is bank primary source of income (Wei et al., 2019: p. 26). Meanwhile, credit assets face unavoidable risk. This is highest frequency risk and biggest influence business. Once bank suffers credit risk, profit of bank will be influenced seriously even affecting the stability of local economic, such as Lehman brothers bank. Hence, analyzing financial statement to discover uncover credit risk effec- 
tively is very crucial for bank to manage credit assets. According to Blankespoor et al., (2011: p. 1151), the ability of leverage and credit risk have a strong relationship, which means that leverage can reflect credit risk of bank industry well. Specifically, higher leverage brings higher credit risk. For example, Blankespoor et al., (2011: p. 1143) shows the relationship between leverage and credit risk of 46 bank holding companies in 80393 trading days (Figure 4). This result explains that they have positive relationship. According fair value calculate method, when leverage measures is 13.69 , credit risk is $0.66 \%$. With the increasing of leverage measures, the credit risk also rises.

In addition, loan is a type of bank business which mostly cause credit risk. Default result in bank can not get any potential interest earned and the principal in order to have an influence on debt paying ability of bank even operating (Wei et al., 2019: p. 36). Hence, allowance for loan and lease losses is very necessary for bank to avoid credit risk. Actually, this type of allowance is a good financial tool of capital for bank to absorb estimated loan losses, which should keep to have the ability to absorb and bear the estimated amount of probable losses due default (Wei et al., 2019: p. 36). For example, as the Figure 2 of income statement of bank of America shows, this bank provides 3.4 billion dollars for the allowance

Descriptive Statistics for Bond Yield Test Sample

46 Bank Holding Companies, 195 Bank-Years, 1861 Bonds, 80,393 Bank-Bond-Trading Days from 1998-2010

\begin{tabular}{|c|c|c|c|c|c|c|}
\hline & $\mathrm{N}$ & Mean & Std Dev & P25 & Median & P75 \\
\hline \multicolumn{7}{|l|}{ Bank-Year Descriptives } \\
\hline Total Reported Assets (in millions) & 195 & 319,159 & 503,266 & 42,780 & 93,287 & 262,159 \\
\hline Total Reported Liabilities (in millions) & 195 & 292,487 & 463,357 & 38,542 & 84,634 & 250,665 \\
\hline Market Value of Equity (in millions) & 195 & 41,873 & 61,621 & 3652 & 15,219 & 51,037 \\
\hline Market to Book Value of Equity & 195 & 1.82 & 0.70 & 1.29 & 1.89 & 2.32 \\
\hline Loans/Assets & 195 & $61.2 \%$ & $15.3 \%$ & $53.0 \%$ & $66.8 \%$ & $72.3 \%$ \\
\hline Deposits/Liabilities & 195 & $70.2 \%$ & $13.2 \%$ & $64.7 \%$ & $72.5 \%$ & $80.6 \%$ \\
\hline Held-to-Maturity Securities/Securities & 195 & $2.4 \%$ & $4.3 \%$ & $0.0 \%$ & $0.1 \%$ & $1.7 \%$ \\
\hline \multicolumn{7}{|c|}{ Leverage Measures (Financial Instrument Measurement Rule) } \\
\hline Fair Value & 195 & 13.69 & 6.18 & 9.84 & 12.02 & 15.43 \\
\hline As Reported per GAAP & 195 & 17.80 & 5.74 & 14.32 & 16.52 & 10.49 \\
\hline (TIERI) & 195 & 13.38 & 3.28 & 10.98 & 13.21 & 15.24 \\
\hline \multicolumn{7}{|l|}{ Credit Risk-Related Descriptives } \\
\hline Non Accrual Loans/Assets (NonAccrLoans) & 195 & $0.66 \%$ & $0.64 \%$ & $0.25 \%$ & $0.41 \%$ & $0.83 \%$ \\
\hline Past Due Loans/Assets (PastDueLoans) & 195 & $0.25 \%$ & $0.32 \%$ & $0.06 \%$ & $0.13 \%$ & $0.27 \%$ \\
\hline OREO/Assets (OREO) & 195 & $0.10 \%$ & $0.13 \%$ & $0.02 \%$ & $0.06 \%$ & $0.13 \%$ \\
\hline Absolute Maturity Gap/Assets (AbsMaturityGap) & 195 & $0.22 \%$ & $0.12 \%$ & $0.14 \%$ & $0.22 \%$ & $0.30 \%$ \\
\hline Net Income/Assets $(R O A)$ & 195 & $0.91 \%$ & $0.76 \%$ & $0.65 \%$ & $0.10 \%$ & $1.40 \%$ \\
\hline \multicolumn{7}{|l|}{ Bond Descriptives } \\
\hline Offering Amount (in millions) & 1861 & 199.9 & 537.8 & 2.6 & 8.2 & 40.0 \\
\hline \multicolumn{7}{|l|}{ Bond Transaction Descriptives } \\
\hline Yield Spread (in basis points) & 80,393 & 248 & 303 & 81 & 153 & 247 \\
\hline Years to Bond Maturity (YrsToMaturity) & 80,393 & 11.0 & 9.0 & 3.6 & 7.8 & 18.8 \\
\hline
\end{tabular}

Figure 4. Descriptive statistics for bond yield test sample. (Source from: Yahoo Finance). 
for loan and leases. On one hand, the provision for loan and leases is complex judgment, which should be decided by managers. Also, according to income statement of bank of America, the loans and leases has the possibility to affect income and profit of the bank even reducing profit. Hence, managers of bank take the responsibility of evaluating and calculating the most appropriate loss to reserve accurately (Wagner, 2019). On the other hand, increasing or decreasing of loans and leases is a very important factor for bank manager to expect the problem loans (Bellini, 2013: p. 390). Specifically, when the loans and leases decrease, reliable loans will arise. Conversely, uptrend of the loans and leases means that bank is holding more problem loans and more credit risk. An increasing number of loans and leases will cause that bank can not afford own debt and liquidity risk (Li et al., 2017: p. 677). Hence, it is very important and useful for bank to analyze income statement to find and avoid credit risk.

Another nonnegligible risk which reflects in financial statement for bank is interest rate risk. Difference between lending at interest rates and the rates paid to depositors can cause interest rate risk due to the spread between interest paid on deposits and received on loans over time (Wagner, 2019). Typically, deposits belong to a type of short-term investment. This means that it can adapt to current interest rate faster (Langer et al., 2014: p. 526). According to Langer et al., (2014: p. 526), along with the increasing of interest rate, bank can increase the rate on variable-rate loans and new fixed-rate loans. Nevertheless, the rate of deposit has great difference with the long-term rates when long term rates are used to price loan rates. Specifically, the increasing of long-term rates have no influence on deposit rate (Wagner, 2019). Therefore, when interest rate increases, bank can make more interest profit. In contrast, as the decreasing of interest rate, bank has more possibility to face interest rate risk due to interest profit declines. Langer et al., (2014: p. 529) point put that bank usually increases the fee income of products and services to avoid interest rate risk. The reason is that the increasing of this type of income can reduce the reliant on the interest income of loans in order to decline interest rate risk.

Besides that, bank stock returns have a negative relationship with changes in interest rates (Fraser et al., 2002: p. 366). According to Fraser et al., (2002: p. 366), bank interest rate risk has an inseparable relationship with basic assets and liability reflecting in financial statement. Usually, more equity capital what bank owns means less interest rate risk, which includes loan and demand deposit to expand assets. Hence, observing and analyzing the characteristics of bank financial statement can help bank manager to manage risk exposure.

\subsection{Analysis of Solvency}

Solvency refers to the ability of bank to pay debts which includes principal and interest (Kashif et al., 2016: p. 2). The ability to pay debts on time is an important indicator of the financial position of a bank. According to Kashif et al., (2016: p. 2), by analyzing solvency, the ability of operating a business and avoid 
risk can be demonstrated and help predict the future profit of bank. solvency of bank includes both short-term solvency and long-term solvency.

\section{Analysis of Short-Term Solvency}

A significant benefit of financial statements is that it can reflect short-term solvency for banks to understand guarantee of repayment of current liabilities. According to Kashif et al., (2016: p. 3), short-term solvency is a type of the degree of guarantee that a bank repays current liabilities on time and reflect the ability of a bank to repay currentliability with current assets. Generally, financial workers of abankuse it to checkthe ability of repaying daily debts and measure the current financial capabilities of a bank. It is an essential indicator for bank to understand the liquidity of liquid assets. According to calculate current ratio, quick ratio, and cash flow liabilities, financial workers can understand shortterm solvency. For example, this Table 1 shows the current ratio of China Bank of Communications.

Hence, according to the analysis results, China Bank of Communications' current ratio has remained above 1 in recent years. Since there is no inventory in the banking industry, the current ratio can be regarded as the quick ratio, which means that the bank's current assets are sufficient to repay the enterprise (Wei et al., 2019: p. 45). China Bank of Communications has excellent short-term solvency. The current ratio increased from 1.03 in 2010 to 1.34 in 2012 (Figure 5). The short-term solvency of China Bank of Communications has improved, indicating that China Bank of Communications has maintained good liquidity in the face of stable financial markets. Therefore, this means that China Bank of Communications has less possibility to face liquid risk and more investment chances for investors.

Table 1. Current ratio of China Bank of Communications.

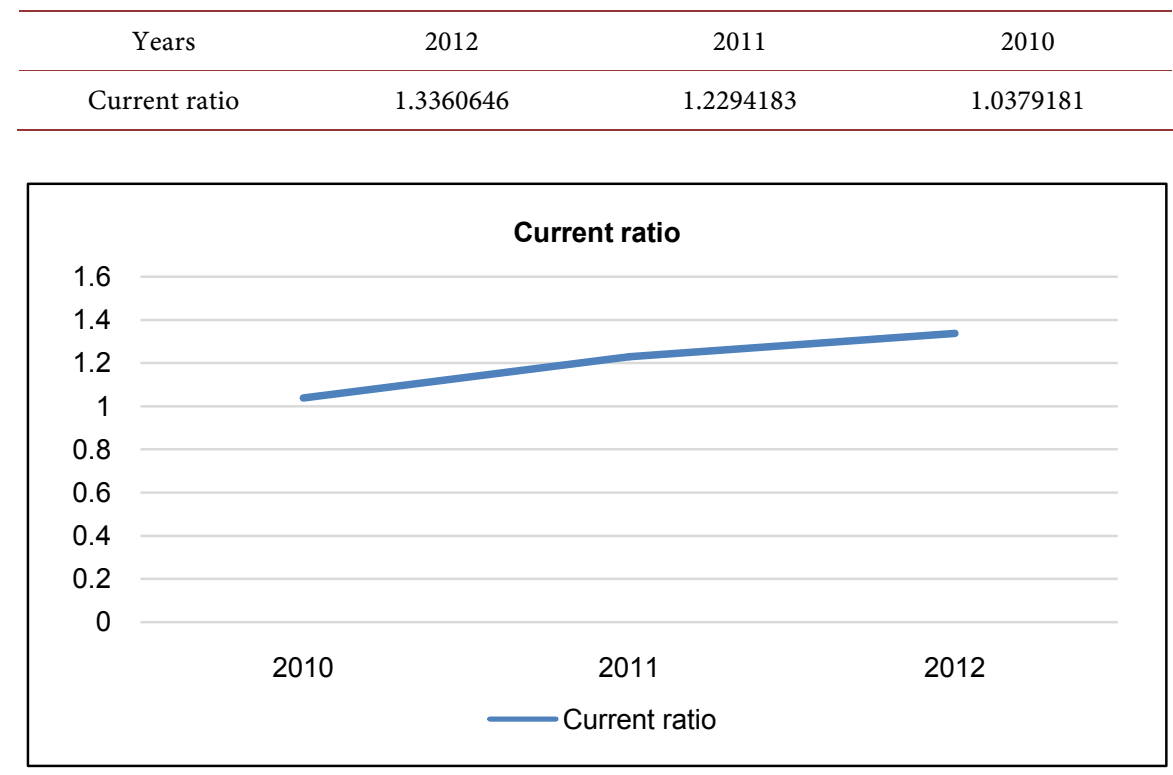

Figure 5. Current ratio. 


\subsection{Analysis of Profitability}

Profit is the purpose and motivation of a bank's survival and development. Krause et al., (2017: p. 119) describes that profitability refers to the bank's ability to earn profits and is related to the ultimate realization of the interests of the various groups of the bank. The financial indicators for evaluating the bank's profitability mainly include return on net assets, return on total assets, net assets per share, earnings per share, and net income from operating income.

\subsubsection{Return on Net Assets}

It is widely accepted that investors and managers can understand return on net assets for financial statements to evaluate the value of a bank. Return on net assets refers to the percentage of net profit and average net assets of a company over a certain period of time. The return on net assets can also be called the return on equity, the rate of return on equity. Reflect the compensation received by shareholders for their rights and interests (Grundke, 2009: p. 211). The higher the indicator, the higher the income from the owner's investment and the stronger the profitability of the company's capital; on the contrary, the weaker the profitability of the company's capital. For example, this Table 2 shows the return on net assets of China Bank of Communications.

As can be seen from the Figure 6, China Bank of Communications' ROE declined in 2010-2012, which led investors to not be optimistic about the company's future development prospects (Wei et al., 2019: p. 45). This could cause less investors to further investment. Hence, this means that profitability is declining so that this bank has more possibility to face competitive risk, which leads to more customers leaving.

Table 2. Return on net assets of China Bank of Communications.

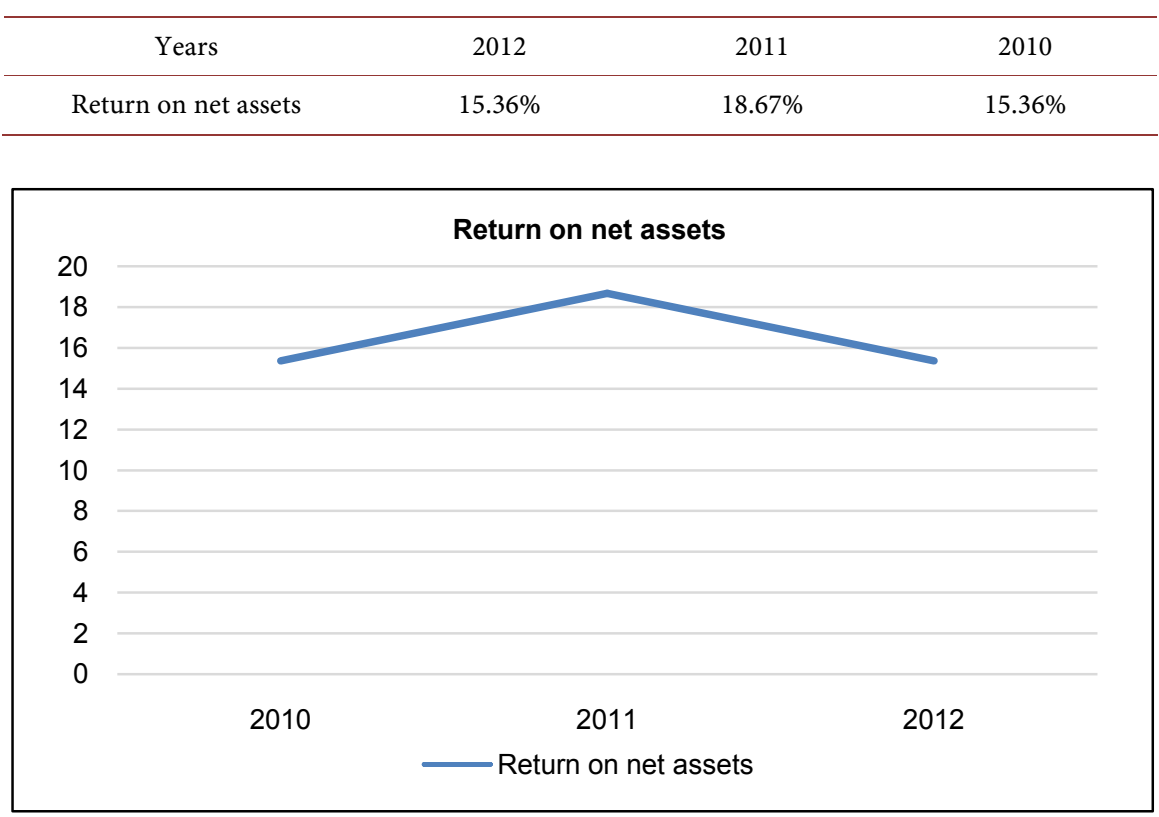

Figure 6. Return on net assets. 


\subsubsection{Earnings per Share}

Many shareholders and investors evaluate income and earnings per share according to analyze financial statements. Earnings per share refers to the corporate profits or corporate losses that each ordinary shareholder can enjoy for each share, reflecting the operating results of listed companies (Li et al., 2017: p. 656). It is an important basis for investor and manager of a bank to measure and evaluate the profitability and investment risks evenpredict the growth potential of the company and make some important financial indicatorrelated to business decisions. It reflects the level of profit per share of ordinary shares. The higher the earnings per share, the higher the net income per share (Bellini, 2013: p. 391). For example, Table 3 shows the earnings per share of China Bank of Communications.

As can be seen from the Figure 7, China Bank of Communications' earnings per share continued to grow in 2010-2012, indicating that the average income level of Bank of Communications shareholders increased (Wei et al., 2019: p. 46). Hence, this is a good reference for stockholder to provide additional investment. In contrast, if earnings per share keep declining, stockholder should consider to reducing shareholding and bank managers should check facing operational risk or not.

\subsection{Analysis of Operation Ability}

\section{Current Asset Turnover}

Another significant benefit of financial statements is that current asset turnover can be calculated to show the capital utilization. The current asset turnover refers to the ratio of the operating income of a bank to the average balance of

Table 3. Earnings per share of China Bank of Communications.

\begin{tabular}{cccc}
\hline Years & 2012 & 2011 & 2010 \\
\hline Earnings per share & 0.88 & 0.82 & 0.66 \\
\hline
\end{tabular}

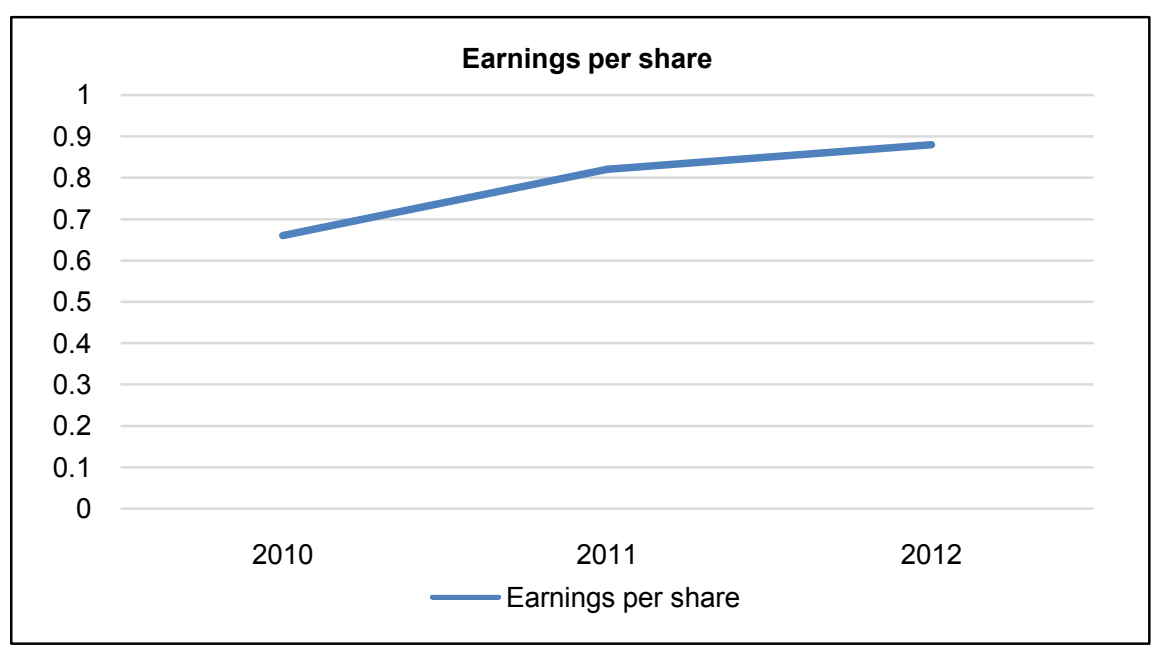

Figure 7. Earnings per share. 
current assets in a certain period of time, or the number of turnovers of current assets. Bellini (2013: p. 389) supports the view that current asset turnover rate expressed in terms of time is the current asset turnover days reflecting the turnover rate of liquid assets, used to measure the efficiency of the use of liquid assets. The faster the index turns, the more economic assets will be saved, which is equivalent to the relative expansion of asset investment, which increases the profitability of the bank, indicating that the capital utilization effect is better (Artis \& Hoffmann, 2008: p. 461). Conversely, the need to supplement the current assets to participate in the turnover will result in waste of funds and reduce the profit of the enterprise ability. For example, Table 4 shows the current assets turnover of China Bank of Communications.

It can be seen from the Figure 8 that the current asset turnover rate of China Bank of Communications in 2010-2012 has decreased year by year, indicating that China Bank of Communications' current assets need to be further improved in terms of utilization efficiency (Wei et al., 2019: p. 46). Unfortunately, this could lead to the waste of funds and reduce the profitability. Hence, bank managers should supplement the current assets in case of liquid risk.

\section{Conclusion}

In conclusion, this essay analyzes the function of financial statements for a bank to use it as operation guideline and explain how useful for a bank to invest and avoid risks. Different parts of financial statement contribute unique use value for bank. Specifically, to understand the solvency, financial workers in a bank can analyze cash flow statement to check the operation position and profit of a bank,

Table 4. Current assets turnover of China Bank of Communications.

\begin{tabular}{cccc}
\hline Years & 2012 & 2011 & 2010 \\
\hline Current assets turnover & 0.15 & 0.16 & 0.17 \\
\hline
\end{tabular}

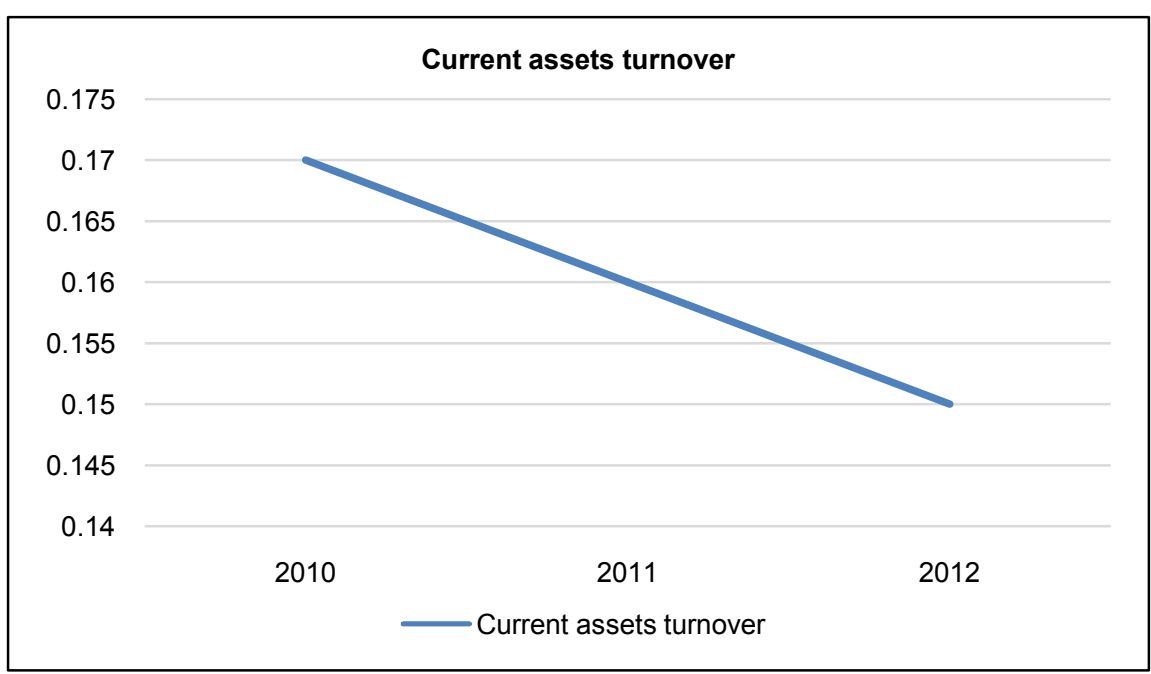

Figure 8. Current assets turnover. 
which shows different activities have different effects on bank investing. This can help managers of bank to find problems in operation and management. For example, if cash flow of a bank shows negative net cash flow, this can speculate that this bank has some problems in operating or managing. Excessive liability may cause this situation, which means that bank may be facing liquid risk.

Income statement can reflect the profitability of a bank helping bank to predict the future profit. It also provides a reference for manager and investor to understand the operating results and investment efficiency. In addition, it can reflect that profit distribution and profit growth is reasonable or not. If growth ratio between two business cycles is too much different, this bank is facing management risk. If profit distribution between deposit and loan has a large difference, this bank has more possibility to face interest rate risk.

In addition, it is very important and useful for bank to find and avoid credit risk. Hence, allowance for loan and lease losses is very necessary for bank to avoid credit risk, which can help bank relieve stress when problem loan increasing. Balance sheet can show asset and liability. According to calculate, managers can understand current asset turnover and return on net asset to analyze financial position of bank. If deposit in balance sheet is too less, loan ability of a bank will be affected. This situation will cause that lower loan growth even more liabilities.

\section{Conflicts of Interest}

The author declares no conflicts of interest regarding the publication of this paper.

\section{References}

Artis, M., \& Hoffmann, M. (2008). Financial Globalization, International Business Cycles and Consumption Risk Sharing. Scandinavian Journal of Economics, 110, 447-471. https://doi.org/10.1111/j.1467-9442.2008.00546.x

Barnes, D., \& Warman, N. (2000). Is Securitisation Still a Useful Balance Sheet Tool? Balance Sheet, 8, 14-18. https://doi.org/10.1108/09657960010338544

Bellini, T. (2013). Integrated Bank Risk Modeling: A Bottom-Up Statistical Framework. SSRN Electronic Journal, 230, 385-398. https://doi.org/10.1016/j.ejor.2013.04.031

Berger, A., Ghoul, S., Guedhami, O., \& Roman, R. (2015). Internationalization and Bank Risk. SSRN Electronic Journal, 63, 2283-2301. https://doi.org/10.2139/ssrn.2661740

Blankespoor, E., Linsmeier, T., Petroni, K., \& Shakespeare, C. (2011). Fair Value Accounting for Financial Instruments: Does It Improve the Association between Bank Leverage and Credit Risk? SSRN Electronic Journal, 88, 1143-1178. https://doi.org/10.2308/accr-50419

Breuer, T., Jandačka, M., Rheinberger, K., \& Summer, M. (2010). Does Adding Up of Economic Capital for Market and Credit Risk Amount to Conservative Risk Assessment? Journal of Banking \& Finance, 34, 703-712.

https://doi.org/10.1016/j.jbankfin.2009.03.013

Brown, S. (2012). Quantitative Measures of Operational Risk: An Application to Funds Management. SSRN Electronic Journal, 52, 1001-1011. 
https://doi.org/10.1111/j.1467-629X.2012.00506.x

El Fayoumi, K. (2018). The Balance Sheet Effects of Oil Market Shocks: An Industry Level Analysis. Journal of Banking \& Finance, 95, 112-127. https://doi.org/10.1016/j.jbankfin.2017.12.011

Fraser, D., Jeff, M., \& Weigand, R. (2002). Sources of Bank Interest Rate Risk. Financial Review, 37, 351-367. https://doi.org/10.1111/0732-8516.00002

Green, J. (2013). Financial Statement Analysis and Equity Valuation. SSRN Electronic Journal, 1, 1-33. https://doi.org/10.2139/ssrn.2271238

Grundke, P. (2009). Importance Sampling for Integrated Market and Credit Portfolio Models. European Journal of Operational Research, 194, 206-226. https://doi.org/10.1016/j.ejor.2007.12.028

Kashif, M., Iftikhar, S., \& Iftikhar, K. (2016). Loan Growth and Bank Solvency: Evidence from the Pakistani Banking Sector. Financial Innovation, 2, 1-13. https://doi.org/10.1186/s40854-016-0043-8

Krause, T., Sondershaus, T., \& Tonzer, L. (2017). Complexity and Bank Risk during the Financial Crisis. Economics Letters, 150, 118-121. https://doi.org/10.1016/j.econlet.2016.11.026

Langer, T., Goedde-Menke, \& Pfingsten, A. (2014). Impact of the Financial Crisis on Bank Run Risk-Danger of the Days after. Journal of Banking \& Finance, 40, 522-533. https://doi.org/10.1016/j.jbankfin.2013.11.028

Li, J., Wei, L., Lee, C., Zhu, X., \& Wu, D. (2017). Financial Statements Based Bank Risk Aggregation. Review of Quantitative Finance and Accounting, 50, 673-694. https://doi.org/10.1007/s11156-017-0642-0

Penman, S. (2012). Financial Statement Analysis and Security Valuation (5th ed.). New York: McGraw-Hill.

Sasmaz, M. (2015). A 1904 Episode in Self-Regulation: Arthur Lowes Dickinson and the Development of the Income Statement. Research in Accounting Regulation, 27, 190-192. https://doi.org/10.1016/j.racreg.2015.09.010

Shopify (2019). Financial Statement Definition-What Is Financial Statement. https://www.shopify.com/encyclopedia/financial-statement

Subramanyam, K. (2014). Financial Statement Analysis. New York: McGraw-Hill Education.

Valand, P. (2011). A Study of Financial Statement. Indian Journal of Applied Research, 1, 8-10. https://doi.org/10.15373/2249555X/SEP2012/4

Wagner, H. (2019). Analyzing a Bank’s Financial Statements. New York: Investopedia. https://www.investopedia.com/articles/stocks/07/bankfinancials.asp

Wei, L., Li, G., Zhu, X., \& Li, J. (2019). Discovering Bank Risk Factors from Financial Statements Based on a New Semi-Supervised Text Mining Algorithm. Accounting \& Finance, 37, 1-54. https://doi.org/10.1111/acfi.12453 